\title{
THE SOUTHERN HEMISPHERE GLACIAL RECORD - ANTARCTICA AND NEW ZEALAND
}

\author{
by T. J. Chinn,
}

(with one table, two text-figures and two plates)

Chinn, T.J., 1996 (xi): The Southern Hemisphere glacial record — Antarctica and New Zealand. In Banks, M.R. \& Brown, M.J. (Eds): CLIMATIC SUCCESSION AND GLACIAL HISTORY OF THE SOUTHERN HEMISPHERE OVER THE LAST FIVE

MILLION YEARS. Pap. Proc. R. Soc. Tasm. 130(2): 17-24. https://doi.org/10.26749/rstpp.130.2.17

ISSN 0040-4703. Institute of Geological and Nuclear Sciences, PB 1930, Dunedin, New Zealand.

The New Zealand terrestrial glacial record and that of the Dry Valleys area, McMurdo Sound, Antarctica are compared in a chronological table of events. The Antarctic chronology given is that of a stable East Antarctic Ice Sheet hypothesis, while an alternative postulates a Pliocene collapse of the ice sheet. Whereas the New Zealand record commences at about $2.5 \mathrm{Ma}$, the Antarctic record commences in detail at $15 \mathrm{Ma}$. Following the New Zealand late Pliocene glacial events, a hiatus of over one million years occurs where the combined effects of uplift and erosion have almost entirely removed the terrestrial record. The ages of the Antarctic sequence have been determined by Arl Ar dates of volcanic ash associated with the deposits, while the older New Zealand events have been dated by association with fluctuating sea levels and sequence counts. Younger New Zealand events are relatively well constrained by radiometric dates. The New Zealand Pleistocene concludes with a rapid warming at c. $14 \mathrm{ka}$ which heralded the demise of the huge Pleistocene glaciers, while in Antarctica the end of the Pleistocene is marked by the disappearance of marine Ross Sea ice.

Key Words: glacial chronology, glacial geology, Antarctica, Dry Valleys, New Zealand

\section{INTRODUCTION}

\begin{abstract}
The stones of the Antarctic dance in the katabatic disco to the eternal tunes of the thermal shuffle and permafrost creep. [author]
\end{abstract}

\section{The Character of Antarctic Glaciations}

Glacial processes occurring in Antarctica have fundamental differences from those operating in temperate areas, and these differences lead to differing responses to global climate changes. Antarctic air and ice temperatures are normally so low that there is no melt of any significance, and a climate warming serves only to increase snowfalls, so that advance rather than retreat is the glacier response.

Ice of dry-based or polar glaciers is below pressure melting point and is frozen to the glacier bed. Such slow-moving, dry-based glaciers have limited or no erosive powers, carry little debris and deposit characteristic sandy tills. The nature of the glacial deposits varies with the temperature and different sources of ice. Ice sheet overriding the Dry Valleys area initially left wet-based (clayey) tills from warm and/or thick ice on the high plateaux and in range cirques. Later deposits of cold and/or thin ice are sandy, dry-based tills. Tills of the deep outlet glaciers associated with overriding are normally wet-based in the valley floors, changing to dry-based tills at higher elevations. Local glaciers formed in the cooler climates since the last overriding were almosr invariably dry-based, leaving deposits of both redistributed material and local lithologies. Up-valley invasions by Ross Sea ice have left extensive valley-floor moraines and tills of wet-based character and very mixed lithologies. These deposits interfinger with the deposits of down-valley ice. Minor uplift of the valleys was contemporaneous with the glacial events, and shallow fiords filled the Wright and Taylor Valleys between glaciations.
Antarctic ice volumes are linked to worldwide glacial and interglacial periods through changing sea levels and the floating ice shelves. When sea levels fell during the cool glacials, the ice shelves grounded on the continental shelf and thickened from local precipitation. Adjacent arid areas, like the Dry Valleys region, were invaded by inland-flowing ice of the "marine" Ross Sea glaciations. Meanwhile, the interior ice sheet became lower because of a diminished snow supply. During the warmer interglacial periods, increased continental snowfalls caused the ice sheet to expand, while the coastal ice shelves retreated, steepening the gradients and increasing the discharge of the outlet glaciers.

\section{The "Stable Ice Sheet" Hypothesis}

The Antarctic glacial history given here is that of the Dry Valleys area of McMurdo Sound (fig. 1) and is based largely on recent workin the western Asgard Range and Wright and Taylor Valleys, which was presented as a case for a stable East Antarctic Ice Sheet (EAIS) during the Pliocene (Marchant et al. 1993). The stable EAIS theory postulates that the ice sheet has been stable for approximately 14 million years, and that the continent has been subject to unbroken, cold polar conditions during this period (Sugden et al. 1993, Denton et al. 1993, Hall et al. 1993, Prentice et al. in press). Correlations with the Victoria Valley sequence are from geological mapping work by Isaac et al. (1996). The timing of the major early events given in this chronology is critically dependent on the reliability of $\mathrm{Ar} / \mathrm{Ar}$ dates of tephras within the Asgard Range deposits (Marchant et al. 1993) and on similar dates from Wright Valley (Hall et al. 1993) and Taylor Valley (Wilch et al. 1993). These events and dates conflict with the theory that the EAIS collapsed and reformed during the Pliocene. 


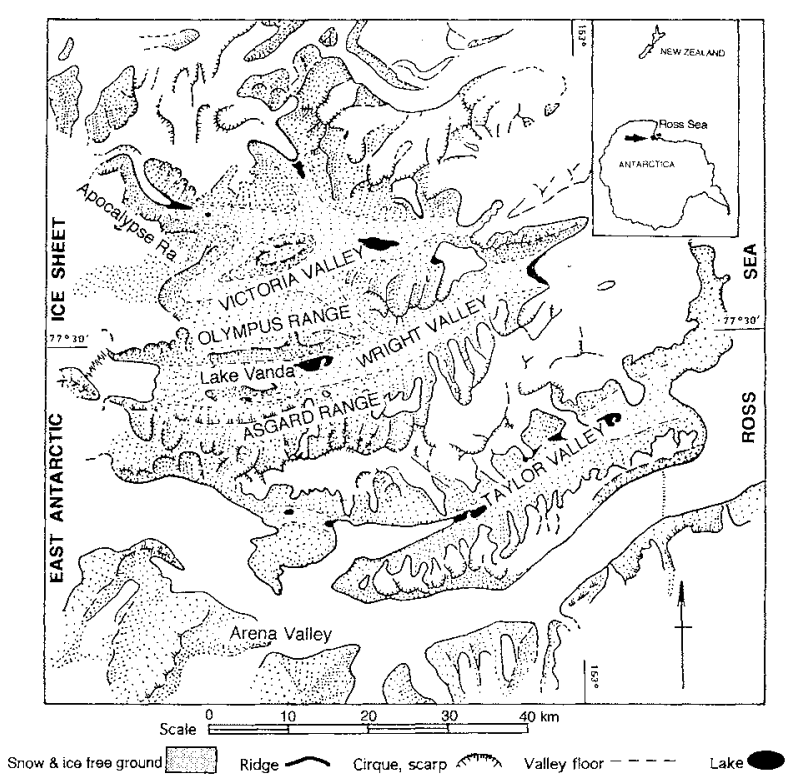

FIG. 1 - The Dry Valleys region, McMurdo Sound.

\section{The "Meltdown" Theory}

An alternative hypothesis is based on the presence of Pliocene marine diatoms in the high-altitude glacial tills of the Sirius Formation. The presence of the diatoms implies that the EAIS had collapsed in the Pliocene and open sea existed to the inland side of the Transantarctic Mountains. A late Pliocene regrowth of the EAIS then overrode the Transantarctic Mountains, emplacing the diatom-laden Sirius Formarion (Mercer 1972, Webb \& Harwood 1987).

\section{GLACIAL HISTORY CHRONOLOGY}

The chronology of glacial history in Antarctica and New Zealand is shown in table 1 . This table is a "best guess" in the face of mutually conflicting or undated data. The Antarctic part was developed for the gelogical map presented in Isaac etal. (1996) and is based on papers of the volume Geografiska Annaler $75 \mathrm{~A}$ (4). A full set of all references consulted is given with the map. The New Zealand part is based mainly on the review by Suggate (1990).

\section{Ice-Sheet Overriding Prior to $15.2 \mathrm{Ma}$}

The Antarctic glacial record commences over an order of magnitude earlier than that of temperate regions. The present landscape was shaped in late Oligocene to upper Miocene times (table 1) by wer-based continental ice repeatedly overriding a fluvially dissected landscape (Webb 1990, Hall et al.1993). The earliest evidence of Antarctic glaciation is from glaciomarine sediments in a McMurdo Sound Sediment and Tectonic Studies (MSSTS) core, which indicate the presence of icebergs from $31 \mathrm{Ma}$ in Late Oligocene (Harwood 1986). From this extensive period, wet-based tills of the Sirius Formation, containing in situ wood fragments of Nothofagus sp. and diatom assemblages of inferred early Pliocene age, survive on the oldest high surfaces of the Transantarctic Mountains (Mercer 1972, McKelvey et al. 1991).
Towards the end of the Miocene, recession of continental ice was associated with a cooling climate that changed the nature of the glaciers from wet-based (temperate) to drybased (polar), and glacial erosion effectively ceased beneach all but deep ice streams.

\section{Prior to $15.2 \mathrm{Ma}$ - Late Miocene Weathering}

There followed a period of deep subaerial weathering and colluviation under cold desert conditions, synchronous with a fiord in Wright Valley, that produced the highly oxidised and poorly sorted Koenig Colluvium, with welldeveloped ventifacts (Marchant et al. 1993). This colluvium is widely distributed throughout the Asgard Range.

\section{2-14.8 Ma - Local Glaciation Following Ice-Sheet Withdrawal}

Following the withdrawal of continental ice, an early episode of alpine glaciation in the western Asgard Range is recorded by Sessrumnir Till, found in the base of depressions in Asgard Range cirques. Underlying bedrock striae indicate down-valley ice flows (Marchant et al. 1993). The till is of a wet-based glacier origin, probably from a local glacier, and antedates volcanic ash deposits of $15.2-14.8 \mathrm{Ma}$.

\section{5-13.6 Ma - The Last Ice-Sheet Expansion}

The last major ice-sheet expansion event is recorded by three till deposits. Asgard Till records rising ice levels at the mouths of the high cirques, Jotunheim Till comprises mainly redistributed deposits recording climax ice levels, and Peleus Till was left in the main valleys by the associated ourlet glaciers. There are no deposits recording recession of this event, although the Bull Drift deposits of Victoria Valley suggest a complex of rising and falling ice levels (Isaac et al. 1996).

Deposits of Asgard Till are directed into the mouths of cirques along the Asgard, Olympus and Apocalypse Ranges (Claridge \& Campbell 1978, Marchant et al. 1993) and are interpreted as a still-stand during rising levels of this event. The age of the deposit is greater than 13.6 million years inferred from volcanic ash found in sand wedges (Marchant et al. 1993).

Jotunheim Till represents the culmination of thick northeast-flowing ice that engulfed the Asgard Range and reworked colluvial deposits, rock glacier deposits and regolith (Denton et al. 1984, Marchant et al. 1990). The ice flowing through the Asgard Range was close to pressure melting point and is associated with meltwater erosion features and wet-based abrasion of the low-lying cirque headwall saddles. Ash dates indicate that the event finished prior to $10.5 \mathrm{Ma}$ and probably occurred between 15.2/ 14.8 and $13.6 \mathrm{Ma}$ (Marchant et al. 1993).

This whole period of the last ice-sheet overriding is represented by Peleus Till which blankets much of the floor and southern wall of Wright Valley, with its upper limit descending eastward from $1150 \mathrm{~m}$ elevation. Peleus Till overlies Miocene glaciomarine silt in DVDP 4 a in Lake Vanda (Cartwright et al. 1974). In the middle of Wright 
Valley, the till is overlain by Alpine III and IV moraines of local alpine glaciers. The volume and variety of Bull Drift deposits surviving in Victoria Valley suggest that the Peleus was a multiple, long-duration episode (Isaac et al. 1996).

\section{5-5.5 Ma - Alpine Cirques Empty}

From 12.5 to $5.5 \mathrm{Ma}$ the alpine cirques were empty of ice during a long period of cold desert climate, and the Alpine glaciers did not acquire their present form until about $5.5 \mathrm{Ma}$, when the Alpine IV and Alpine III expansions entered the shallow Jason Fiord which filled Wright Valley prior to tectonic uplift to present levels. From ${ }^{40} \mathrm{Ar} /{ }^{39} \mathrm{Ar}$ and other dates, the Alpine IV expansion was constrained to $>3.7 \mathrm{Ma}$ and the Alpine III to $<3.5 \mathrm{Ma}$, probably between 3.2 and $2.5 \mathrm{Ma}$ (Hall et al. 1993). The correlatives in Victoria Valley are extensive deposits of younger Bull Drift.

\subsection{Ma to c. $3 \mathrm{Ma}$ - Cold Desert Cooling}

Following withdrawal of overriding ice, the ice sheet underwent modest expansions to leave the $9.5 \mathrm{Ma}$ Quartermain Drift, and final Bull Drift events in Victoria Valley. During climate cooling and deglaciation from c. $7 \mathrm{Ma}$, the ice sheet and outlet glaciers have no recorded fluctuations until about $3 \mathrm{Ma}$, when the Taylor IVb moraine (pl. 1) records the greatest expansion in the last $3.47 \mathrm{Ma}$ (Wilch et al. 1993).

\section{5-1.8 Ma - Worldwide Cooling}

There is no terrestrial record of this period in Antarctica; presumably all glaciers retreated to behind their present limits. However, New Zealand glaciations commenced at this time.

\section{New Zealand Pliocene Glaciations}

The New Zealand terrestrial glacial record begins in the Late Pliocene when the main South Island mountain ranges had been rising for perhaps two million years (Suggate 1990). The earliest definicive glacial deposit is till of the Ross Glaciation found at Ross in Westland (fig. 2). (Note that this name has no connection with the Antarctic Ross Sea glaciations.) The steeply dipping till lies conformably on Pliocene marine beds and is overlain by marine sandstone and conglomerate of late Pliocene age (Gage 1945). Towards the northeast, extensive accumulations of weathered gravels are attributed to the Ross Glaciation. Associated with and overlying the Ross deposits are thoroughlyweathered Pliocene conglomerates of the Old Man Group. Both of these weathered gravel formations are attributed to an increase of glacial activity. In a separate area to the northeast, weathered till, lake silt and gravel of the Porika Formation (c. 2.1 Ma) lie on basement near the Alps and extend northwards to rest on the extensive Moutere Gravel. Age relationships have been coarsely estimarcd from pollen floras (Mildenhall \& Suggate 1981).

The principal on-land records of both late Pliocene and early Pleistocene time are the marine units from the Wanganui Basin of the western North Island. Here the

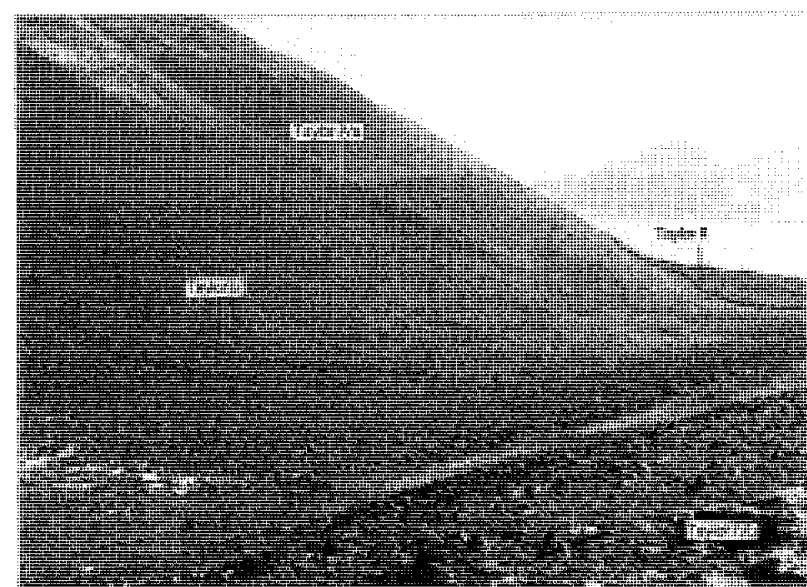

PLATE I

Moraines of higher levels of the Taylor Glacier in Arena Valley. Taylor Glacier and Asgard Range in background.

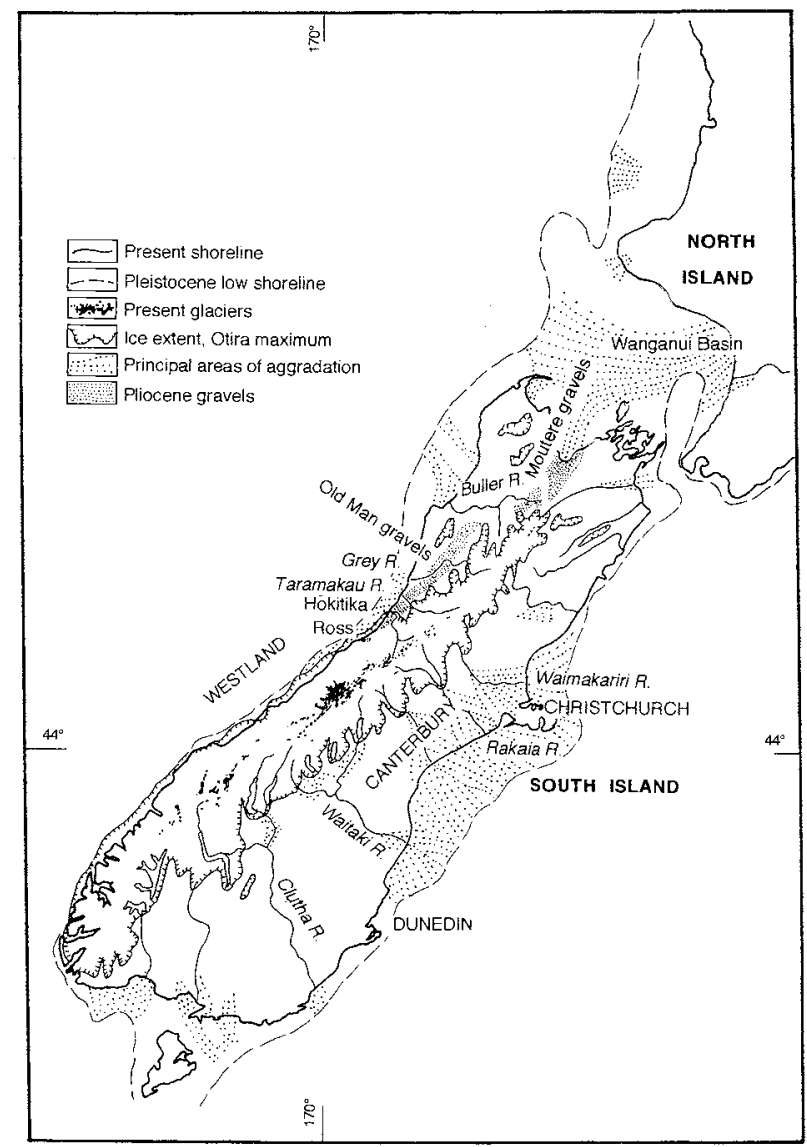

FIG. 2 - New Zealand South Island showing present and Pleistocene glacial extents and shorelines, together with Pliocene and Pleistocene aggradation gravels.

"first marked faunal evidence of cooling of the seas in New Zealand was the abrupt appearance of subantarctic taxa" (Beu et al. 1987), considered to be c. $2.4 \mathrm{Ma}$ (Edwards 1987). If this earliest major cooling is associated with the Ross Glaciation, it is no better dated than the 2.6-2.4 Ma range. 
TABLE 1

Glacial history - an Antarctic-New Zealand correlation

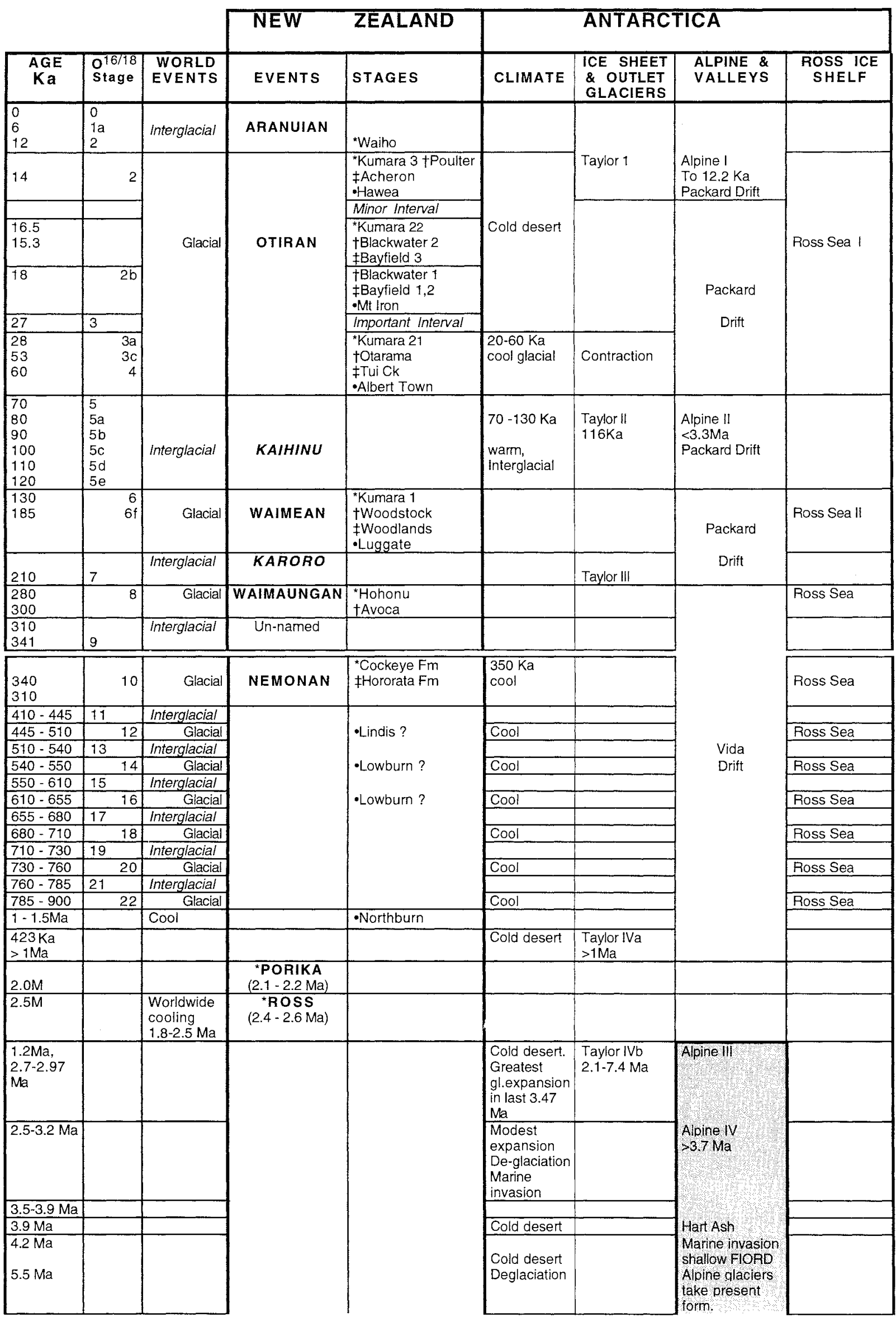


TABLE $1-$ cont.

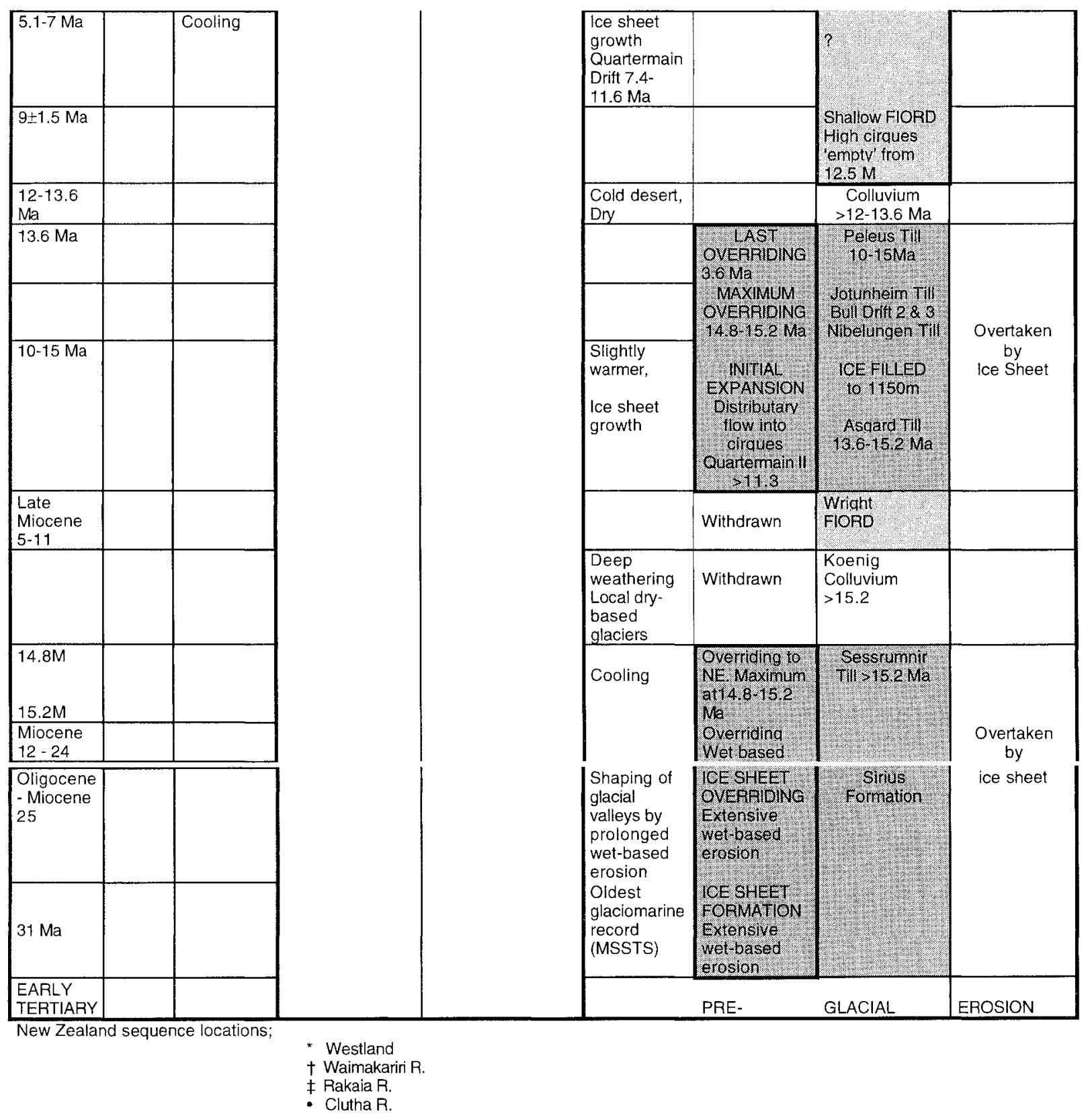

\section{New Zealand Early to Mid Pleistocene}

After the Pliocene, apart from sparse evidence from Westland and weathered gravels in the upper Clutha Valley, there follows a major gap of well over a million years in the South Island record of glacial deposits (Suggate 1990). Combined effects of rapid uplift and erosion have destroyed most evidence of glaciation from c. $2.1 \mathrm{Ma}$ until the last $0.35 \mathrm{Ma}$. Westland evidence is from marine terraces which may extend back to $0.7 \mathrm{Ma}$, inferred to represent interglacial episodes alternating with glacial outwash surfaces. In the upper Clutha Valley (pl. 2), Northburn, Lowburn and Lindis Tills and Gravels have yielded U/Th dates that indicate that the Lindis event is of Isotope Stage 10 or 12 and that Northburn deposits may be up to one million years in age (McSaveney et al. 1992).

\section{Antarctic Early to Mid Pleistocene}

It has been demonstrated that local and alpine glaciers expanded during Pleistocene incerglacial periods (Hendy et al. 1979, Denton et al. 1989) and the complex Vida Drifts of Victoria Valley (Calkin 1971) are assigned to these warmer events. Small expansions of the ice sheet and corresponding rise in outlet glacier levels, also assumed to be in response to interglacial warming, are represented by the Taylor IVa moraines (pl. 1). Inland-flowing Ross Sea glaciations characterise the Pleistocene interglacials (Stuiver et al. 1981). Widespread drifts of erratics in the floors of most main valleys are attributed to these early Ross Sea events. 


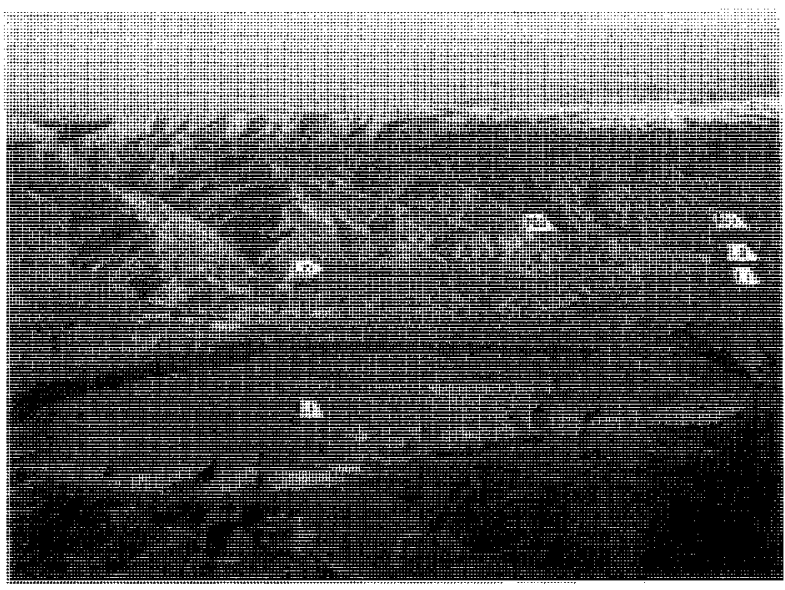

PLATE 2

The older glacial deposits of the upper Chutha River, the oldest sequence of glacial events recognised in New Zealand. Ice limits indicated are: No, Northburn; Lo, Lowburn; Li, Lindis and Lindis moraine.

\section{Antarctic Mid to Late Pleistocene Interglacials}

The moraines of all the late Pleistocene events are close to the present glaciers, lying in positions similar to the "Little Ice Age" moraines of temperate glaciers elsewhere in the world. This indicates that Pleistocene fluctuations have been remarkably small, with recession to behind the present ice extents the most probable dominant position.

Local alpine glaciers expanded during interglacials. From ${ }^{40} \mathrm{Ar} /{ }^{39} \mathrm{Ar}$ and other dates, the Alpine II glaciation in Wright Valley is constrained to $<3.2 \mathrm{Ma}$ and, from surfaces having soil-weathering stage 2 (Hall et al. 1993), is probably late Quaternary in age. The c. $120 \mathrm{ka}$ Taylor II Drift is tentatively correlated with Alpine II moraines (Denton et al. 1993). The hummocky Packard Drift of the Victoria Valley floor grades back to ice-cored moraines of the present glaciers. Packard Drift is undared, but the degree of weathering indicates a mid to late Pleistocene age (Calkin 1971) and is tentatively allocated an age range from Taylor III to the present. Taylor I and Alpine I moraines are in contact with present ice and are younger than 12000 years.

\section{Antarctic Mid to Late Pleistocene Glacials}

The Ross Sea drifts, reaching elevations of 300-400 m, were deposited in the valleys and around the coasts of the Dry Valleys area by infilling of McMurdo Sound by grounded ice (Stuiver et al. 1981). This ice lifted the profiles of the outlet glaciers, where lateral drift sheers record the fluctuations of Ross Sea ice levels (Denton et al. 1989). Associated with the Ross Sea glacials were massive lakes of meltwater which filled the valleys dammed by the inflowing ice. Both Otiran (Wisconsin) and Waimean (Illinoian) have been recognised as Ross Sea I and Ross Sea II respectively, but earlier events have not been differentiated away from outlet glacier marginal drifts. Massive late Wisconsin/Holocene recession of Ross I grounded ice from McMurdo Sound was underway at $13000 \mathrm{yr} \mathrm{BP}$ and completed by $6000 \mathrm{yr} \mathrm{BP}$.

\section{New Zealand Mid to Late Pleistocene Glaciations}

The mid to Late Pleistocene glaciations took place in a setting substantially similar to that of the present day, where valley glaciers characterise all glaciated catchments. Water was plentiful, enabling enormous fluvioglacial deposits like the Canterbury Plains, rather than periglacial features, to be formed. Judged by the generally similar extents of glaciers during the late Pleistocene, conditions for all were basically similar to the last, Otiran Glaciation, when temperature depressions of between $4^{\circ}$ and $6^{\circ} \mathrm{C}$ have been estimated. Deposits of four glaciations commencing at Oxygen Isotope Stage 10 have been identified (Suggate 1990). The Westland glacial sequence appears to have the most complete record (Suggate 1990) and is used here as a reference sequence for the South Island glacial chronology.

\section{The Character of Westland Glaciations}

Glacial sequences of the South Island differ in character east and west of the Divide. North Westland deposits range from valley glacier moraines and down-valley outwash trains of the Buller River area, to piedmont ice of the Grey and Taramakau Rivers and large valley glaciers that flowed out to sea south of Hokitika (fig. 2).

In the northern sector, uplift has preserved a sequence of interglacial shorelines cut into the glacial outwash plains. This unique relationship of moraine, outwash surface and marine cliffs has enabled a detailed dated sequence of late Pleistocene events to be established for north Westland (Suggate 1990). At least six shorelines extending up to $80 \mathrm{~m}$ above present sea level have been recognised, the highest being substantially older than the Nemona Glaciation (table 1).

\section{Character of the Glacial Sequences of the Eastern South Island}

To the east of the Main Divide, the glaciations are characterised by couples of moraines and their ourwash surfaces, each couple being successively higher and further down-valley, and each outwash steeper, with age (Gage 1958, Soons 1963). The main features used for correlation have been the youngest principal moraines and outwash aggradational surfaces in each area. Radiocarbon dates constrain the later Otiran events, while older advances are correlated on the basis of weathering of gravels and physiographic development. External data from sites such as the DSDP off-shore drill Site 594 (Nelson et al. 1985) have permitted marine Oxygen Isotope Stages to be tentatively applied to the terrestrial glacial sequences (table 1).

\section{The Last Major New Zealand Pleistocene Advance}

The last major Pleistocene advance is quite well constrained by radiocarbon dates, commencing somewhat before $22.3 \mathrm{ka}$ and culminating at $18 \mathrm{ka}$ (Suggate 1990). All associated pollen floras indicate cold conditions. The younger and smaller Kumara 3 advance is less well dated and probably 
occurred between about 16 and $14 \mathrm{ka}$. The rapid warming at c. $14 \mathrm{ka}$ heralded the demise of the huge Pleistocene glaciers and the beginning of the present (Aranuian) interglacial. There followed several dated but poorly correlated "late glacial" readvances between 12 and $8 \mathrm{ka}$ before the interglacial climatic optimum of the Holocene. A south Westland moraine, the Waiho Loop, has yielded a number of radiocarbon dates, many of which are coincident with the commencement of the Northern Hemisphere Younger Dryas event $\left(11000^{14} \mathrm{C}\right.$ yr BP).

\section{The New Zealand Holocene}

Throughout the Southern Alps, glaciers contracted rapidly to a small fraction of their Pleistocene extents, between 12 and $9 \mathrm{ka}$ but with a number of dated re-advances (Gallatly et al. 1988). Several moraines have been dated in the period 9000 to $7600 \mathrm{yr} \mathrm{BP}$, although there is other evidence of marked warming between 9000 and $5000 \mathrm{yr}$ BP. Neoglacial activity commenced at $5000 \mathrm{yr} \mathrm{BP}$ and continued to the present, with numerous well-documented glacial fluctuations. Nested moraines indicate that the advances diminished in size only slightly towards the present.

\section{PRESENT GLACIER EQUILIBRIUM}

\section{Antarctica}

The present glaciers of the Dry Valleys are approximately in equilibrium (Bull \&x Carnein 1970, Chinn 1985). Movement races of the polar glaciers are two orders of magnitude slower than those of temperate glaciers, and so are the changes. Measured changes of frontal positions show that these glaciers are fluctuating in proportion to their flow and ablation regimes as dynamically as do temperate glaciers. Both advances and recessions are presently occurring, but there is no trend towards either advance or retreat. Many of the present cirque glacier moraines are disproportionately large for the size of the glacier, suggesting that these glaciers have remained within the confines of their existing moraines for at least 3 to 5 million years.

\section{New Zealand}

The New Zealand glaciers have been receding, often dramarically, from their maximum "Little Ice Age" extents attained towards the end of last century. However, since 1983 there has been a reversal of this trend, and currently almost all of the glaciers are advancing (Chinn 1995).

\section{ACKNOWLEDGEMENTS}

I wish to express my thanks to Dr A. Ruddell for providing the opportunity to present this paper at the 1995 ANZAAS Conference in Hobart, and to Jane Forsyth for a very useful review of the manuscript.

\section{REFERENCES}

Beu, A.G. Edwards, A.R. \& Pillans, B.J., 1987: A review of New Zealand Pleistocene stratigraphy, with emphasis on the marine rocks. PROCEEDINGS OF THE FIRST INTERNATIONAL COLLOQUIUM ON QUATERNARY STRATIGRAPHYOF ASIA PACIFIC AREA: 250 269.

Bull, C. \& Carnein, C.R., 1970: The mass balance of a cold glacier: Meserve Glacier, south Victoria Land, Antarctica. Int. Assoc. Sci. Hydrol. Publ. 86 (ISAGE): 429-446.

CALKIN, P.E., 1971: Glacial geology of the Victoria Valley system, southern Victoria Land, Antarctica. In Crary, A.P. (Ed.) ANTARCTIC SNOW AND ICE STUDIES II: 363-412.

Cartwright, K., Treves, S.B. \& Toril, T., 1974: Geology of DVDP 4, Lake Vanda, Wright Valley, Antarctica. Dry Valley Drill. Proj. Bull. 3: 49-74.

Chinn, T.J.H., 1985: Structure and equilibrium of the Dry Valleys glaciers. NZ Antarct. Rec. 6 (spec. issue):73-88

Chinn, T.J.H., 1995: Glacier fluctuations in the Southern Alps of New Zealand decermined from snowline elevations. Arct. Alp. Res. 27(2); 187-198.

Claridge, G.G.C. \& Campbell, I.B., 1978: Moraines of probable Miocene age, Dry Valleys, Antarctica. NZ Antarct. Rec.1(2): 1-5.

Denton, G.H., Prentice, M.L., Kellogg, D.E. \& Kellogg, T.B., 1984: Late Tertiary history of the Antarctic ice sheet: Evidence from the Dry Valleys. Geology 12: 263267.

Denton, G.H., Bockheim, J.G., Wilson, S.C. \& Stuiver, M., 1989: Late Wisconsin and early Holocene glacial history, inner Ross embayment, Antarctica. Quat. Res. 31: 151182.

Denton, G.H., Sugden, D.E., Marchant, D.R., Hall, B.L. \& WILCH, T.I, 1993: East Antarcric Ice Sheer sensicivicy to Pliocene climate change from a Dry Valleys perspective. Geogr. Ann. 75A (4): 155-204.

EDWARDS, A.R., 1987: An integrated biostratigraphy, magnetostratigraphy and oxygen isotope stratigraphy for the late Neogene of New Zealand. NZ Geol. Surv. Rec. 23.

GAGE, M., 1945: The Tertiary and Quaternary geology of Ross, Westland. Trans. R. Soc. NZ 75: 138-159.

GAGE, M., 1958: Late Pleistocene glaciation of the Waimakariri valley, Canterbury, New Zealand. NZ J. Geol. Geophys. 1: $103-122$.

Gellatly, A.F., Chinn, T.J.H. \& Röthlisberger, F., 1988: Holocene Glacier variations in New Zealand: a review. Quat. Sci. Rev. 7: 227-242.

Hall, B.L., Denton, G.H., Lux, D.R. \& Bockheim, J.G., 1993 : Late Tertiary paleoclimate and ice-sheet dynamics inferred from surficial deposits in Wright Valley. Geogr. Ann. 75A (4): 239-267.

HARWOOD, D.M , 1986. Oldest record of Cainozoic glacial-marine sedimentation in Antarcrica (31 Myr): Results from MSSTS-1 drill-hole. SAfr. J. Sci. 82: 516-519.

Hendy, C.H., Healy, T.R., Rayner, E.M., Shaw, J. \& Wilson, A.T., 1979: Late Pleistocene glacial chronology of the Taylor Valley, Antarctica, and global climate change. Quat. Res. 11: 172-184.

Isaac, M.J., Chinn, T.J., Edrrooke, S.W. \& Forsyth, P.J., 1996: GEOLOGY OF THE OLYMPUS RANGE AREA, SOUTH VICTORIA LAND, ANTARCTICA. Institute of Geological and Nuclear Sciences geological map. Scale 1:50,000. Institute of Geological and Nuclear Sciences Ltd, Lower Hutt, New Zealand.

Marchant, D.R., Denton, G.H. \& Sugden, D.E., 1990: Surficial geology of Sessrumnir Valley, wescern Asgard Range, Antarcrica: implications for lare Terriary ice-sheet overriding. Antarct. J. US 1990 Rev. xxv (5): 53-55. 
Marchant, D.R., Denton, G.H., Sugden, D.E. \& Swisher, C.C., 1993: Miocene glacial stratigraphy and landscape evolution of the western Asgard Range, Antarctica. Geogr. Ann. 75A (4): 303-328.

McKelvey, B.C., Webe, P.N., Harwood, D.M. \& Mabin, M.C., 1991: The Dominion Range Sirius Group: a record of the late Pliocene-early Pleistocene Beardmore Glacier. In Thomson, M.R.A., Crame, J.A. \& Thomson, J.W. (Eds): GEOLOGICAL EVOLUTION OF ANTARCTICA. Cambridge University Press: 675-682.

McSaveney, M.J., Thomson, R. \& Turnbull, I.M., 1992: Timing and relief of landslides in Central Otago, New Zealand. In Bell, D.H. (Ed.): LANDSLIDES GLISSEMENTS DE TERRAIN. Proceedings of the Sixth International Symposium, Christchurch. A. A. Balkema, Rotterdam: 1451-1456.

MerCer, J.H., 1972: Some observations on the glacial geology of the Beardmore Glacier area. In Adie, R.J. (Ed.): ANTARCTIC GEOLOGY AND GEOPHYSICS. Universitetsforlaget, Oslo: 427-433.

Miloenhall, D.C. \& Suggate, R.P. 1981: Palynology and age of the Tadmore Group (late Miocene-Pliocene) and Porika Formation (early P'leistocene), South Island, New Zealand. NZ J. Geol. Geophys. 24: 515-528.

Nelson, C.S., Hendy, C.H., Jarrett, G.R. \& Cuthbertson, A.M., 1985: Near synchroneity of New Zealand alpine glaciations and Northern Hemisphere continental glaciations during the past $750 \mathrm{kyr}$. Nature 318 (6044): 361-363.
Prentice, M.L., Bockheim, J.G., Willson, S.C., Burckle, L.H., Hodell, D.A., Schluchter, C. \& KellogG, D.E., in press: Late Neogene Antarctic glacial history: evidence from central Wright Valley. Antarct. Res. Ser. Am. Geophys. Union.

Soons, J.M., 1963: The glacial sequence in part of the Rakaia valley, Canterbury, New Zealand. NZ J. Geol. Geophys. 6: 735-756.

Stuiver, M., Denton, G.H., Hughes, T.J. \& Fastook, J.L., 1981: History of the marine ice sheet in West Antarctica during the Last Glaciation: a working hyporhesis. In Denton, G.H. \& Hughes, T.J. (Eds): THE LAST GREAT ICE SHEETS. John Wiley and Sons, NY: 319-436.

Sugden, D.E., Marchant, D.R. \& Denton, G.H., 1993: The case for East Antarctic Ice Sheet: The background. Geogr. Ann. 75A (4):151-153.

Suggate, R.P., 1990: Late Pliocene and Quaternary glaciations of New Zealand. Quat. Sci. Rev. 9: 175-197.

Webb, P.N., 1990: The Cenozoic history of Antarctica and its global impact. Antarct. Sci. 2 (1): 3-21.

Webb, P.N. \& Harwood, D.M., 1987: The Sirius formation of the Beardmore Glacier region. Antarct. J. US 22: 8-12.

Wilch, T.I., Denton, G.H., Lux, D.R. \& Mcintosh, W.C., 1993: Limited Pliocene glacier extent and surface uplift in middle Taylor Valley, Antarctica. Geogr. Ann. 75A (4): $331-351$.

(accepted 14 May 1996) 